be referred to onshore incision in the African erosion cycle. These offshore results merely add to the overwhelming body of evidence in support of the framework which de Swardit wishes to discredit.

(4) In assessing the date of inception of the Post-African I erosion cycle, the age of littoral sediments immediately overlying the Post-African I planation surface must be conclusive. Where such sediments have been preserved, not only at Uloa, but along considerable stretches of the South African coast between East London and Saldanha Bay, their age has proved to be Miocene $^{3}$. Simple palaeontological principles do not permit that the Oligocene "Pecten Bed" identified $24 \mathrm{~km}$ offshore during drilling operations is the same biostratigraphical unit as that of Uloa, since both the shark and Pecten fauna at the latter locality have been confidently placed within the Miocene on the basis of reliable evidence $^{4,5}$. The $20 \mathrm{Myr}$ date for the inception of the Post-African I incision can therefore be accepted with confidence. Relationships along considerable stretches of the coast do not indicate a slowly migrating shoreline, but several phases of transgression during the Tertiary ${ }^{3.6}$.

(5) A small margin of error in my assessment of nickpoint migration rates cannot be avoided, as the linear assumption provides for a mean representation, which cannot readily be refined, as the affects of some variables are impossible to measure. This is a potential source of some inaccuracy, but can by no stretch of argument be regarded as fatal to the technique. The absolute range of possible inaccuracies must, of necessity, decrease towards the watershed origin. This range is considered to be sufficiently small to permit the technique to be used to derive general orders of age and a relative sequence of dates for cave opening-all that I originally claimed for my results.

(6) Numerous erosional nickpoints in South Africa can be recognised through careful fieldwork. Their cyclic associations are not difficult to determine through the application of careful morphormetric and statistical analyses such as formed the basis for my anticle. Erosional nickpoints are clearly distinguishable from those of lithological or local tectonic origin.

(7) Decline in nickpoint migration rates upstream is by no means exclusively a function of diminishing dischange. Owing to large scale PlioPleistocene upwarping of the South African coastal margins, many rivers show substantially steeper gradients along their lower courses than in higher reaches; for example, between the Orange River mouth and Prieska, the mean channel gradient is $0.9 \mathrm{~m}$ $\mathrm{km}^{-1}$; between Prieska and Buxton on the Harts River the gradient is $0.4 \mathrm{~m}$ $\mathrm{km}^{-1}$.

(8) Variations in nickpoint migration rates between trunk and tributary channels are, indeed, taken into account in my analysis, since my measurements are related to the actual channel segments concerned. Varying conditions along such segments have naturally affected the present positions of the nickpoints which have migrated along them, upon which my graphs are based. The limited inaccuracies which may result from small-scale fluctuations between observation points have been considered.

(9) The validity of my method and assumptions is further confirmed by two age estimates based on entirely different techniques. My estimate of 4.8 Myr for the $61 \mathrm{~m}$ terrace of the Vaal River at Windsorton ${ }^{7}$, based on the same methods used to estimate dates of first cave opening, is generally confirmed by the presence at this locality of elephant remains which existed some $4 \mathrm{Myr}$ ago in the East African potassium-argon chronology ${ }^{8}$. Moreover, Butzer ${ }^{9}$, in a lengthy analysis to be published in December, has independently arrived at a maximum age estimate almost identical to my own for the Taung hominid deposit.

22 St. Andrews Road,

PO Box 31023,

Braamfontein,

Johannesburg, South Africa

${ }^{1}$ Maud. R. R., Z. Geomorphol., 7, 155 (1968).

${ }^{2}$ King, L. C., The Natal Monocline (University of Natal, Durban, 1972).

${ }^{3}$ Siesser. W. G.. Trans. geol. Soc. S. Afr., 75, 177 (1972).

4 King, L. C., Geol. Mag., 106 (2), 206 (1969).

${ }^{5}$ King, L. C., Trans. geol. Soc. S. Afr., 74, 241 (1971).

${ }^{6}$ King, L. C., Z. Geomorphol., 16, 239 (1972).

${ }^{7}$ Partridge, T. C., and Brink, A. B. A., S. Afr. geogr. J., 49, 21 (1967).

${ }^{8}$ Maglio, V. J., Nature, 225, 328 (1970).

- Butzer, K. W., Curr. Anthropol. (in the press).

\section{Ascorbic acid and nitrosamine}

SIR-Edgar ${ }^{1}$ has proposed that ascorbic acid might inhibit the carcinogenic action of nitrosamines and other carcinogens that may act by alkylation. The rationale was that ascorbate might be alkylated in vivo before the carcinogens can react with cell macromolecules. The experimental basis for Edgar's thesis was that statement by Kamm et $a .^{2}$ that ascorbate inhibited the liver necrosis induced by dimethyl- nitrosamine (DMN). This statement, however, was presented without experimental details and was subsequently withdrawn ${ }^{3}$.

The main concern of the study by Kamm et al. was the inhibition by ascorbate of the liver toxicity induced by oral administration of aminopyrine plus nitrite. This study followed our report in 1972 suggesting, on the basis of in vitro experiments, that ascorbate might be used to block in vivo formation of $\mathrm{N}$-nitroso compounds from nitrosatable chemicals (for example, drugs), since ascorbate efficiently reduces nitrate ${ }^{4}$. Subsequently, the report of Kamm et al. ${ }^{2}$ appeared. Greenblatt $^{5}$ found similar results in mice to those of Kamm et al., but stated that ascorbate did not affect DMN toxicity. We found that ascorbate prevented liver damage from gavage of dimethylamine plus nitrate to rats and, from experiments presented in detail, that ascorbate did not significantly affect the production by DMN of liver necrosis and elevated serum transaminase levels ${ }^{6}$. Ascorbate did not affect transplacental carcinogenesis in rats by ethylnitrosourea, but inhibited carcinogenesis by ethylurea plus nitrite ${ }^{7}$.

We are concerned that our original suggestion should not be extended without basis to the hypothesis that ascorbate might have a much wider inhibitory action on carcinogens. The interesting suggestion of Edgar is not supported by the results reviewed here, which were mostly made public after Edgar's paper was submitted.

Yours faithfully,

S. S. MIRvish
P. SHrubIK
Eppley Institute for Research in

Cancer,

University of Nebraska Medical Center, Omaha, Nebraska 68105

${ }^{1}$ Edgar, J. A., Nature, 248, 136-137 (1974).

${ }^{2}$ Kamm, J. J., Dashman, T., Conney, A. H., and Burns, J. J., Proc. natn. Acad. Sci. U.S.A., 70, 747-749 (1973).

${ }^{3}$ Kamm, J. J., Dashman, T., Conney, A. H., and Burns, J. J., in N-Nitroso Compounds in the Environment (edit. by Bogovski, P., Walker, E. A., and Davis, W.) (International Agency Research Against Cancer, Lyon, in the press).

4 Mirvish, S. S., Wallcave, L., Eagen, M., and Shubik, P., Science, 177, 65-68 (1972).

s Greenblatt, M., J. natn. Cancer Inst., 50, 1055-1056 (i973).

${ }^{6}$ Cardesa, A., Mirvish, S. S., Haven, G. T., and Shubrik, P., Proc. Soc. exp. biol. Med., 145, 124-128 (1974).

7 Ivankovic, S., Preussmann, R., Schmähl, D., and Zeller, J., in "N-Nitroso Compounds in the Environment (edit. by Bogovski,, P., Walker, E. A., and Davis, W.) (International Agency Research Against Cancer, Lyon, in the press). 